\title{
The legacy of public action and gender-sensitivity of the pandemic response in Kerala State, India
}

\section{R. Ramakumar ${ }^{1}$ (D) $\cdot$ Mridul Eapen ${ }^{2}$}

Received: 1 March 2021 / Accepted: 30 September 2021 / Published online: 19 October 2021

(C) Springer Nature Switzerland AG 2021

\begin{abstract}
Kerala State, India has received global attention in its response to the Covid-19 pandemic. Its response effectively attended to the health pandemic and focussed on economic relief. This paper attempts to understand how gender-responsive Kerala's policies were. Kerala's success was due to its historical preparedness and contemporary policy innovations. Over the years, public action was able to ensure that the state and the society were equipped to meet the challenges of a disaster, such as of the pandemic. In the 1990 s, when India sought to limit state intervention and promote market-based solutions, public policy in Kerala shifted gears to deepen state intervention by promoting community participation and empowering women. As in other Indian States, the pandemic in Kerala too led to losses of female employment, rise in gender-based violence, a deterioration of women's mental health and rise in unequal care burdens. But Kerala's response was distinctive. Several policy interventions had foregrounded women's needs, which helped ensure gender-sensitivity in Kerala's pandemic response. Kerala's economic relief package included cash support, employment, free food provision and zero-interest loans to women. Through helplines, the government reached out and helped women report instances of violence and mental stress. The gender-sensitivity of Kerala's pandemic response is a rich guide as a demonstration of its possibilities and a reminder of the essential prerequisites to achieve it.
\end{abstract}

Keyword Kerala $\cdot$ India $\cdot$ Covid-19 $\cdot$ Pandemic $\cdot$ Gender-responsive policy $\cdot$ Gender sensitivity

\section{R. Ramakumar}

rr@tiss.edu

1 School of Development Studies, Tata Institute of Social Sciences, Deonar, Mumbai 400088, India

2 Centre for Development Studies, Prasanth Nagar, Thiruvananthapuram 695011, India 
JEL Classification O200 Development Planning and Policy: General · O210 Planning Models; Planning Policy · O53 Asia including Middle East · P470 Other Economic Systems: Performance and Prospects · P480 Other Economic Systems: Political Economy; Legal Institutions; Property Rights; Natural Resources; Energy; Environment; Regional Studies · P000 Economic Systems: General · H410 Public Goods · H510 National Government Expenditures and Health · H520 National Government Expenditures and Education · H530 National Government Expenditures and Welfare Programs · H550 Social Security and Public Pensions · H750 State and Local Government: Health; Education; Welfare; Public Pensions . H840 Disaster Aid · I150 Health and Economic Development · I140 Health and Inequality · I380 Welfare, Well-Being, and Poverty: Government Programs; Provision and Effects of Welfare Programs

This paper deals with the engagement of public policy with the experiences of women during the Covid-19 pandemic in Kerala State, India. Kerala is widely considered as a model region in the developing world in designing and implementing a "gender-responsive" strategy to address the fall-out of the pandemic. Our attempt is to document this response strategy and understand the historical and contemporary reasons behind Kerala's success.

The paper, first, highlights the importance of Kerala's socioeconomic and institutional preparedness to address the pandemic. Secondly, the paper documents the impact of the pandemic on women in Kerala. Thirdly, the paper presents an analysis of the responses of the State's government to the health pandemic and the economic crisis with special reference to women. Fourthly, we briefly highlight the reasons why Kerala's pandemic response was successful as "gender-responsive" when compared to other parts of India.

\section{Pandemic, women and the choice of Kerala}

\subsection{Unequal impacts of the pandemic}

Studies from across the world show that the impacts of Covid-19 pandemic were harsher on women than men (Agarwal, 2021a, 2021b; Alon et al., 2020; Croda \& Grossbard, 2021; Kabeer, 2020; Linde \& Gonzalez, 2020; Wenham et al., 2020).

First, the lockdown disrupted formal and informal labour markets leading to losses in employment. Female jobs were more vulnerable than male jobs, particularly in the informal labour market. Hence, loss of jobs was more permanent and widespread for women than men. As economic resources were distributed unequally across men and women, the ability of women to cope with the economic shock also stood circumscribed. The "digital gender divide" was wide; as a result, the ability of women to regain jobs was also poorer than of men.

Secondly, women were in the forefront of public responses to the pandemic given the gender division of labour in the fields of public health, caregiving and sanitation. 
Women in these fields were already over-worked due to the strains on public funding and inadequate staff strengths. The health pandemic further increased the work burden on women in such occupations, and, in the process, left them more susceptible to infections.

Thirdly, the lockdown was accompanied by school closures. Home-schooling became the norm. This phenomenon led to heightened demands on women to be more involved in household chores and participate in the home-schooling of children, even as many among them continued to work from home.

Fourthly, women at home were increasingly exposed to domestic violence from partners and spouses during the lockdown. The Secretary-General of the United Nations, Antonio Guterres, spoke of the "horrifying global surge in domestic violence" and noted that "for many women and girls, the threat looms largest where they should be safest: in their own homes" (United Nations, 2020).

Fifthly, every country with a lockdown reported a rise in the number of women suffering from mental health issues. Phumzile Mlambo-Ngcuka, the Executive Director of UN Women, noted that "confinement [was] fostering the tension and strain created by security, health and money worries" (ibid.). As women had less access to phones and helplines, and as crucial public services like police, judiciary and social services remained disrupted, the deterioration of mental health was more pronounced for women than men.

In summary, the lockdown exacerbated the vulnerabilities historically faced by women inside and outside homes. The UN Women expects that gender gap in poverty and inequality would rise and about 47 million women and girls would be pushed into poverty due to Covid-19 (UN Women, 2020). There have been universal calls for "gender-responsive policies" so that the hard-won gains of the past are protected, and the future could be "built back fairer".

\subsection{The focus on Kerala}

It is in this context that we attempt to study the pandemic with reference to women in Kerala. It was in Kerala that the first case of Covid-19 was registered in India on 30 January 2020. Yet, Kerala has had the lowest case fatality rate (CFR) among all Indian States. ${ }^{1}$ As on 21 May 2021, India's CFR was 1.1 per cent, while Kerala's CFR was only 0.3 per cent. The comparison was striking for three reasons. First, most other States had a lower caseload than Kerala, but a higher CFR. For instance, the number of persons per million who had tested Covid-positive was 65,299 in Kerala, but only 19,703 in India. Secondly, deaths due to Covid-19 were more accurately recorded in Kerala compared to other States, where the death registration system is poorly developed. In contrast, about 92 per cent of all deaths were registered in the vital registration system of Kerala in $2020 .^{2}$ Therefore, the difference between

\footnotetext{
1 The data was retrieved from https://www.covid19india.org/state/KL.

2 Completeness of registration of deaths (CoRD) was recorded at 77 per cent in India in 2015, as per data from the fourth National Family Health Survey (NFHS-4). State-wise data from the fifth National Family Health Survey (NFHS-5) in 2019-20 show that if 98 per cent of all deaths in the previous three years were registered with the civil authorities in Kerala, the corresponding share was only 37.1 per cent in a State like Bihar.
} 
Table 1 Comparison of deaths in Kerala with selected developed countries, 2019 and 2020

\begin{tabular}{llllll}
\hline State/country & $\begin{array}{l}\text { Covid-19 } \\
\text { deaths/1000 } \\
\text { persons }\end{array}$ & $\begin{array}{l}\text { Total deaths } \\
\text { (all-cause mor- } \\
\text { tality), 2019 }\end{array}$ & $\begin{array}{l}\text { Total deaths } \\
\text { (all-cause mor- } \\
\text { tality), 2020 }\end{array}$ & $\begin{array}{l}\text { Crude death } \\
\text { rate per 1000 } \\
\text { persons, 2019 }\end{array}$ & $\begin{array}{l}\text { Crude death rate } \\
\text { per 1000 persons, } \\
2020\end{array}$ \\
\hline Kerala & 8.4 & 263,901 & 228,739 & 7.55 & 6.81 \\
USA & 106.0 & $1,443,000$ & $1,626,000$ & 8.71 & 9.72 \\
Italy & 124.0 & 435,250 & 475,674 & 14.47 & 15.71 \\
\hline
\end{tabular}

Source: GoK (2021)

Similar robust data are not available for India, due to shortfalls in the registration of vital events

the CFRs of Kerala and other States is likely to be wider. Thirdly, between 2019 and 2020, Kerala recorded a decline of 11.1 per cent in the total number of all-cause deaths (GoK, 2021). The crude death rate fell from 7.5 per 1000 population in 2019 to 6.8 per 1000 population in 2020 , which was an outstanding feat when compared to even developed countries (see Table 1).

If Kerala stood ahead of other Indian States in addressing the health pandemic, it was also a leader in reaching economic relief to the people during the lockdown. In end-March 2020, the State government announced a fiscal package of size Rs 20,000 crore (US\$ 2760 million). The package included a range of in-cash and inkind transfers to the people.

Through the lockdown period in 2020, Kerala's response to the pandemic received global praise. In July 2020, the World Health organisation (WHO) lauded the State for its low death rate and impressive recovery rate (WHO, 2020a). Kerala's response, it said, was a template that "could serve as a great example for other [Indian] States to emulate". In June 2020, Amartya Sen noted Kerala's response to the pandemic as "a transformatory movement" that succeeded in "combating bureaucracy, combating red tape, and doing things with exceeding speed" (PTI, 2020). Sen traced the success of Kerala to "public sector intervention", which was being weakened in other parts of the world. Global media houses, including the $B B C$, The Guardian and Washington Post, commissioned articles documenting Kerala's successful response (for brief commentaries, see Thomas Isaac \& Sadanandan, 2020; Swaminathan \& Johnson, 2020; Chathukulam \& Tharamangalam, 2020; Heller, 2020).

Thus, Kerala's response was unique among all Indian States and, perhaps, several other comparable regions of the world. This was the key reason why we selected Kerala as a site of study in this paper. Our aim is to document and analyse the role and position of women in this experience of pandemic response in Kerala. 


\section{Kerala's preparedness: a history of public action}

Kerala could be described as one of the most prepared regions in the world when the pandemic arrived. The preparedness of Kerala stemmed from a series of historical features as well as contemporary policy innovations. From the 1970s itself, Kerala was globally known for its advances in the fields of land reform, education, health and nutrition (Ramachandran, 1996). Scholars have characterised these achievements of Kerala as products of "public action" from above and below (Sen, 1999; see also Franke, 1993; Parayil, 2000). They were also a springboard for other initiatives in the following decades. In the mid-1990s, the State instituted the "People's Planning Campaign" (PPC). The PPC was a programme of decentralising administration, where at least one-fourth of the plan funds were devolved to elected local self-governments (LSG) to plan their developmental activities (see Thomas Isaac $\&$ Franke, 2002). Then, in the twenty-first century, there were renewed efforts to modernise and upgrade the State's human development architecture (KSPB, 2021b).

The idea of gender empowerment was embedded into these processes and interventions. By gender empowerment, we refer to the process of social change that leads to the improvement of the position of women in society. Important components of such social change are women's access to education, health, livelihood and resources; recognition, reduction and redistribution of their responsibilities in domestic and 'care' work; greater voice in decision making; participation in the process of development and public life; and enhancement of gender consciousness in the society against gender stereotypes and discriminatory norms and practices.

\subsection{Institutional preparedness}

\subsubsection{Land reforms}

Land reforms after 1956-57, when the State was formed in independent India, was a foundational feature of Kerala's developmental achievements (Herring, 1980; Namboodiripad, 1948). It led to a historic agrarian transition and a radical shift in the balance of rural power. Its impact went beyond changes in land tenure; land reforms became the "centrepiece of the programme for social and economic progress in the State" (CDS, 1975, p. 59).

Intrinsically, land reform was important as it weakened the foundations of an oppressive agrarian regime and freed workers from different forms of unfreedom. Kerala's land reforms actively helped advance the cause of women's freedoms. In 2015-16, land was registered either singly or jointly in the name of women in only 10.3 per cent of the landowning households in rural India (Rawal \& Bansal, 2021). 
However, a significantly higher proportion of households in rural Kerala-32 per cent-had land registered either singly or jointly in the name of women. Thus, women in Kerala enjoyed more autonomy within the household and a higher legal share in household wealth as compared to other States.

\subsubsection{Education}

Land reforms were also instrumentally important, as the post-land reform society had favourable conditions for advances in the socioeconomic conditions of the poor (Ramakumar, 2006); this is most evident from the State's advances in education. Historically, educational achievements in Kerala were determined by the person's caste status, which in turn was strongly associated with one's status in the agrarian economy (Jishnudas, 2020; Tharakan, 1984). Land reforms weakened the correlation between access to education and one's position in the caste hierarchy and the agrarian economy (Jeffrey, 1993).

Alongside land reforms, there were two parallel developments after 1957. First, public investment in schooling increased. More schools were established, existing schools were upgraded and new teachers, especially female teachers, were appointed. Secondly, political and social movements initiated mass campaigns to expand access to schooling, particularly among women and disadvantaged social groups. As a result, female enrolment in schools dramatically rose in the 1950s and 1960s. ${ }^{3}$ Most recent data between 2017 and 2020 show that on almost every variable in education and schooling, women in Kerala enjoyed a superior record compared to women in India as a whole.

\subsubsection{Health}

The attainment of improved health indicators was another instrumental benefit of land reforms and female education. In the 1950s, Kerala's health indicators were poor in an absolute sense though marginally better than in other States. Between 1951 and 1960, the infant mortality rate (IMR) in Kerala and India were 120 and 140 respectively. The female life expectancy at birth (LEB) was 50 years in Kerala, and 40.6 years in India. The crude death rate was 38.9 in Kerala and 41.7 in India. In other words, Kerala's health record was not significantly superior to that in other States.

After the 1950s, Kerala leaped ahead of other States in most health indicators, especially among women. Public expenditure on health increased (Ramankutty, 2000). The number of hospital beds per 100,000 persons rose from 85 in 1961 to 259 by 1991. The corresponding figure for India in 1991 was just 77.

\footnotetext{
3 The matrilineal system that existed largely in parts of Kerala played an important role since there was never any organised social opposition to women's literacy or women owning property (Kodoth and Eapen 2005; Ramachandran, 1996). These positive attitudes may have helped considerably when Kerala invested in education in the twentieth century, according to Jeffrey (1987), whose paper was strikingly titled "Governments and Culture: How Women Made Kerala Literate".
} 
Equipped with an egalitarian agrarian structure, a strong record of female education and progressive state policy, Kerala's health and demographic transition began much earlier than in India, and was completed within a single generation (Krishnan, 1991). There were major improvements in fertility rate, birth rate, IMR, death rate, life expectancy at birth and sex ratio after the 1950s. These changes had a significant positive impact on the health status of women.

By the 1990s, Kerala's health sector was considerably stressed by a growing fiscal crisis (George, 1990). It was in this context that the State introduced two transformatory interventions. First, as part of the PPC, health services were decentralised (Elamon, Franke and Ekbal, 2004). As a result, community participation in the health system deepened. The governance of public health centres (PHC) and the provision of drinking water and sanitation were devolved to the LSGs. These led to visible improvements in access to health care for women and disadvantaged communities.

Secondly, a major public investment programme-Aardram-was undertaken from 2016 to upgrade public health institutions. Aardram aimed at investing new resources to transform PHCs into family health centres, increase the number of doctors and nurses, modernise out-patient management procedures, create hygienic and spacious hospital wards, beds and toilets and expand access to low-cost medicines. The programme imparted a new life to Kerala's public health system after 2016.

In sum, even in the second decade of the twenty-first century, Kerala maintained its relative superiority in health indicators, especially in women's health, among all Indian States. Kerala could face the Covid-19 pandemic better than other States because its health infrastructure was better developed than in other Indian States.

\subsubsection{Mental health}

Kerala was also a pioneer State in India that integrated mental health into public health institutions (Maya, 2012). According to one commentary, when "most states do not even have state-level policies or action plans" on mental health care, Kerala was "one of the few states that has a mental health policy and is also ahead in terms of funding, awareness, adolescent care, and the number of available professionals in most districts" (Palepu, 2020).

First, the District Mental Health Programme (DMHP) was strengthened in the 2000s. General care physicians in the PHCs were trained to handle mental health cases, and cases that needed professional assistance were referred to the DMHP clinics. All treatments were provided free of cost. Secondly, a tele-medical health helpline called DISHA was introduced in 2013 that focussed on physical and mental health questions. Thirdly, mental health was introduced in the administration of all schools from 2007 as part of a scheme called UNARV ("awakening"). Teachers were trained in adolescent developmental psychology, and mental health disorders. 
Students were counselled by trained teachers, with provisions to invite experts to provide cognitive behavioural therapy, problem solving skill therapy, and anger management skills (Palepu, 2020). These three systems in Kerala were pioneering in India. In 2016-17, Kerala was the only Indian State that achieved the target of at least one psychiatrist per 100,000 population.

\subsection{Empowerment of women}

Even in the presence of improvements in female education and health, the historical and social transformation of gender relations in Kerala was slow and uneven. An example was the continued presence of patriarchal attitudes and institutions in the society. Patriarchy in contemporary Kerala was visible in a generalised social commitment to confining women to a domestic role, the perception of men as the heads of households and the role of women themselves in internalising patriarchal values. Also, improved literacy and schooling were not accompanied by a concurrent expansion of employment opportunities for educated women. As a result, work participation rates for women remained low. Further, from the 1990s onwards, there was also a rising visibility of domestic violence, conflicts over women's property rights and the growth of dowry (Kodoth \& Eapen, 2005).

Of course, overcoming patriarchy as a social institution is a long social process. While public policy in Kerala was acutely aware of this fact, it also consciously attempted to play a facilitating role in the promotion of women's empowerment. We shall summarise the role of public policy in this regard by highlighting four interventions.

\subsubsection{Gender-aware planning}

From the mid-1990s, Kerala made a commendable effort to incorporate gender concerns into the decentralised planning process. It was mandated that (a) LSGs should set apart 10 percent of their plan funds for the Women Component Plan (WCP); and (b) there should be an assessment of gender impact in all schemes. ${ }^{4}$ Thus, needs of women became prioritised in the developmental plans of LSGs. This policy shift was assisted by the significant numbers of women elected to the LSGs as representatives. From 1996 itself, one-third of all the seats in the LSGs were reserved for women across India; this was later raised to 50 per cent of all the seats in a few States including Kerala. In September 2020, the share of female elected representatives in LSGs was 45.6 per cent in India and 52.4 per cent in Kerala. ${ }^{5}$ In the more recent elections held to the LSGs in Kerala in December 2020, the share of female elected representatives in LSGs rose further to 54 per cent.

\footnotetext{
${ }^{4}$ WCP pertains to that part of the annual plan outlay of the government that must be mandatorily earmarked for women-specific projects.

5 See Government of India's press note available at https://pib.gov.in/PressReleaselframePage.aspx? PRID=1658145, dated 23 September 2020.
} 


\subsubsection{Gender budgeting}

The allocation of funds for women and the efficiency of use of these funds were sought to be enhanced through the preparation of gender budgets (Eapen, 2021). Kerala was the first state to evolve a methodology to disaggregate composite schemes based on gender (Das, 2019). Through a consistent effort to measure and monitor fund flows to women, Kerala ensured that the allocations for women always exceeded the targets set in budgets. For example, in 2017-18, the budget had set a target of 10 per cent of the plan outlay to be spent for women, but the actual allocation was 11.4 per cent (KSPB, 2021a).

\subsubsection{Kudumbashree}

The Kudumbashree Mission was set up in 1998 as a community organization of women's Neighbourhood Groups (NHGs). It aimed at not just the alleviation of poverty, but also the empowerment of women through an expansion of female employment. Though they began with thrift and loan activities, NHGs diversified over time into social entrepreneurship i.e., the creation of self-employment opportunities in health, nutrition, agriculture and microenterprises (Agarwal, 2020; Mukherjee-Reed, 2015; Ramachandran \& Das, 2020; Williams et al., 2011). In 2019-20, Kudumbashree groups had an overall participation of 4.5 million women in over 0.3 million NHGs. Kudumbashree's 68,388 Joint Liability Groups (JLG) of women cultivated about 50,000 acres of paddy land. There were about 28,000 women-led microenterprises involving 64,475 female entrepreneurs, who employed more than 15,000 workers. These microenterprises engaged in a spectrum of activities, such as tailoring, general/kirana stores, coffee shops, tea shops, bag making, construction, and IT units. The Kudumbashree Mission also actively promoted programmes and schemes that addressed atrocities against women.

Thus, the Kudumbashree Mission played a critical role in pulling women out of households into the public sphere by mobilising them, building their individual capabilities and enhancing their choices. Also, in the elections held to the LSGs of Kerala in 2020, more than 7000 of the 21,854 elected representatives were members of Kudumbashree.

\subsubsection{Department of Women and Child Development}

In 2017, the State government set up a Department of Women and Child Development (WCD). The WCD placed substantial emphasis on policies and programmes that addressed gender concerns, such as crimes against women, freedom for women in public spaces, skilling of women for economic empowerment and prioritising the needs of vulnerable women. The interventions of WCD to reduce domestic violence against women are worth highlighting.

First, under the Protection of Women from Domestic Violence Act of 2005, Women Protection Officers (WPO) were appointed in all districts. The WCD formed task forces against gender-based violence and undertook campaigns against dowry. 
The goal was to eliminate dowry. Social media was widely used to target the youth. "Night walks" were organised to boost the confidence of women to travel in public spaces at night.

Secondly, a 24*7 Helpline-Mitra 181-was set up in 2017 to help female victims of violence in the family, public places and workplaces. One Stop Centres named Sakhi were also set up across the State. A third helpline for victims of domestic violence, Bhoomika, was already functional from 2009-10. Nirbhaya Homes (now called "Women and Children Homes") were also established to protect and rehabilitate sexually abused women.

Thirdly, schemes were instituted to provide immediate financial assistance for women and children who were survivors of sexual violence, acid attacks and cruelty. Finally, Jagratha Samithis ("Vigilance Committees") were formed under the State Women's Commission in all the panchayats. These Samithis helped to reduce the distance between rural women and the services provided by various government agencies and acted as a quasi-judicial mechanism at the LSG-level to protect the rights of women and children.

\section{Summary}

Kerala's rich history of land reform, educational advancements, public health care, gender empowerment, progressive governments and a politically conscious citizenry ensured that its institutional ability to mobilise people and the administration was remarkably superior to other States. Also, gender-responsive policy making in Kerala had a history that predated the pandemic. All the prior institutional strengths were brought into full play to contain and address the pandemic after March 2020.

\section{The impact of pandemic on women}

This section deals with the differential impacts of the pandemic on women compared to men. A critical limitation we faced here was the inadequacy of data. In India, a good proportion of statistical information is released with a time lag, and no data are available on many variables of research interest. Thus, while we rely on quantitative data wherever possible, we also use information collected through interviews from government officials, worker's unions, trade associations, and welfare boards.

\subsection{Women's employment and incomes}

First, the size of Kerala's total workforce in 2017-18 was 12.7 million (KSPB, 2020). Of this workforce, 34.5 per cent were regular workers. The size of Kerala's female workforce was 3.3 million. Within the female workforce, 50.4 per cent were regular workers (the corresponding national average was 22.6 per cent). Further, within all regular female workers, 27.5 per cent were covered by 
social security coverage; the corresponding national average was only 11.1 per cent. Regular work does not imply permanency of work, but it helped cushion the female workers from unexpected economic shocks.

Secondly, within Kerala's female workforce, 58 per cent were engaged in the services sector (KSPB, 2020). About half of the women working in the services sector were engaged in the educational and health sectors, which were less affected by the lockdown than other sectors like manufacturing, construction, trade, transport, and hotels and restaurants. Using some assumptions, the Kerala State Planning Board estimated that 57.7 per cent of all workers and 36.8 per cent of female workers in Kerala were affected by the lockdown in 2020. In other words, the employment impact on women would be less than for men.

Thirdly, nevertheless, women formed a significant part of the informal workforce in Kerala. A substantial section of the women's workforce was also concentrated in traditional industries, such as coir, cashew processing, bamboo, handlooms, khadi and plantations. About 43 per cent of the workers in these enterprises were women (KSPB, 2020). As a result, the loss of employment for women in these specific sectors was significant.

Fourthly, a large proportion of women workers were employed in the lower segment of the "informal employment" pyramid i.e., as temporary or part-time workers, contract workers, unregistered or undeclared workers and industrial outworkers (also called home-based workers, or employed without secure contracts, worker benefits, or social protection). The impact of the lockdown in these sectors was severe between March and July 2020, and there were large-scale losses in employment.

Fifthly, several specific sub-sectors that we studied more carefully showed largescale loss of employment for women between March and July 2020 (see KSPB, 2020).

- About 8 million person-days were lost for women in the Mahatma Gandhi National Rural Employment Guarantee Scheme (MGNREGS).

- Kerala also has an Ayyankali Urban Employment Guarantee Scheme (AUEGS). About 0.4 million female person-days were lost under this scheme.

- Under Kudumbashree, there were about 28,000 women microenterprises. The total losses to these enterprises were about Rs 500 million per month (US\$ 6.8 million).

- Most households did not employ domestic workers during the lockdown. Based on information available from the SEWA union, which had 15,000 domestic workers registered with it, we estimated that the daily loss of earnings for a domestic worker was Rs 450-500 (US\$ 6.1-6.7). On an average, each worker would have lost about Rs 12,000 (US\$ 163) per month.

- Most fish vendors were women. They earned Rs 500-1500 (US\$ 6.7-20.4) per day. We estimated that each fish vendor woman would have lost about Rs 12,500 (US\$ 170) in a month. There were also inland fisherwomen. At an average wage of Rs 550 (US\$ 7.5) per day, their loss in earnings was about Rs 14,000 (US\$ 190.2) per month. 
- Most female workers in traditional sectors like reed, bamboo, handloom, and pottery lost work. Each worker earned about Rs 250-300 (US\$ 3.4-4.1) per day, leading to a total loss of about Rs 7,000 (US\$ 95.1) per worker in a month.

- There were close to 0.5 million shops under the Shops and Establishment Act in Kerala, which employed 1.3 million women as saleswomen and cleaning workers. The average salary of a shop employee was about Rs 8000 (US\$ 108.7) per month, and most of them were jobless during the lockdown.

- For example, in Mittayi Street in Kozhikode, a hub of informal women workers that we analysed, there were about 3200 workers earning a daily wage of Rs 400-500 (US\$ 5.4-6.8). All of these workers lost employment, and each worker lost about Rs 11,500 (US\$ 156.3) per month.

- There were more than 0.15 million beauty parlours in Kerala, which employed about 0.4 million female workers. Their average earnings varied from Rs 400Rs 5,000 (US\$ 5.4-67.9) a day, which was their daily loss.

- There were 9864 women who worked as agents of the National Savings Scheme. The average monthly income was Rs 4000 to 50,000 (US\$ 54.3-679.4). Almost all of them were unemployed.

- About 14,000 women worked under the Khadi and Village Industries Board. Their average earning was Rs 350 (US\$ 4.8) per day. The loss in wages for each worker was Rs 7700 (US\$ 104.6) per month.

- About 26,000 women worked in the coir yarn production sector. They earned Rs 350 (US\$ 4.8) per day. The loss per female worker was almost Rs 7350 (US\$ 99.8) per month.

- There were 10 million female workers in the cashew processing sector. They earned Rs 350 (US\$ 4.8) per day and lost earnings to the tune of Rs 7350 (US\$ 99.8) per worker per month.

- About 11,000 women weavers were registered with the weaving cooperatives. The average wage per day was Rs 350 (US\$ 4.8). Thus, each worker lost Rs 7350 (US\$ 99.8) per month.

In sum, it was true that most female workers in Kerala were employed as regular workers in sectors that did not suffer from the lockdown as much as other sectors. Yet, it was also true that employment losses for women were substantial in absolute terms in many sectors in the secondary and tertiary sectors.

\subsection{Crimes against women}

There was a rise in violence against women in Kerala during the pandemic. Monthly data that we put together from one dedicated women's telephonic helplineMitra-181-is provided in Fig. 1. There was a near-doubling of the number of calls received on the helpline that reported domestic violence against women. The number of calls declined marginally with the easing of the lockdown but continued to be large; on an average, if 58 calls were received every month before the lockdown, 113 calls were received every month during the lockdown. The average number of calls 


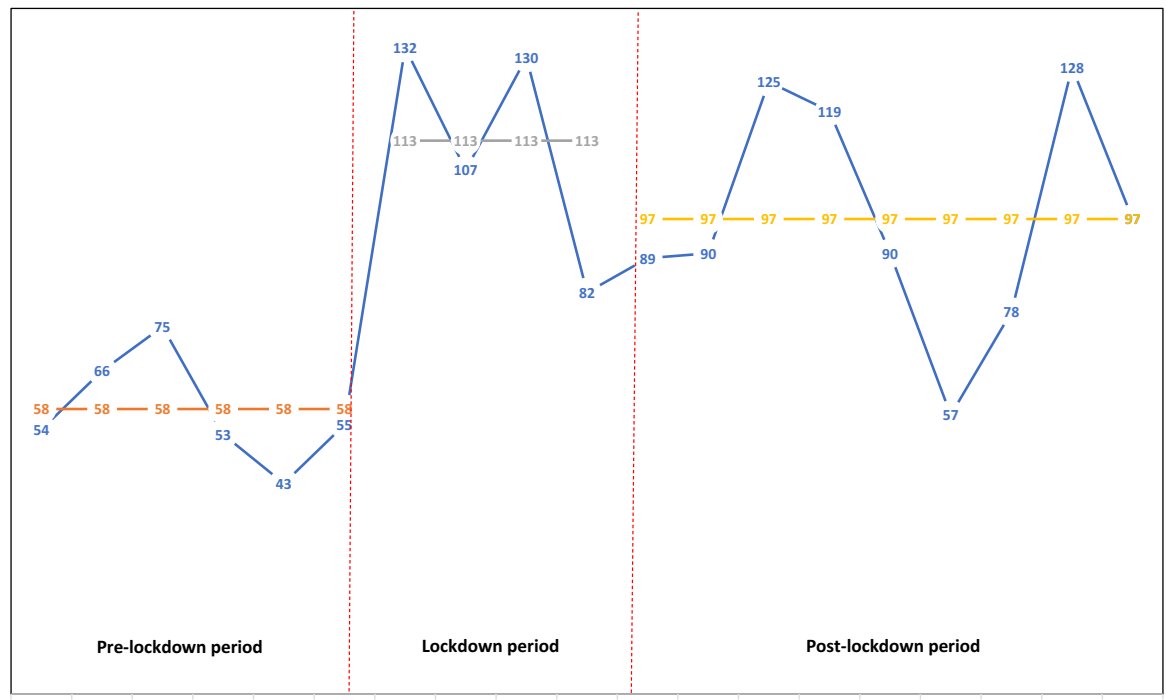

Oct-19 Nov-19 Dec-19 Jan-20 Feb-20 Mar-20 Apr-20 May-20 Jun-20 Jul-20 Aug-20 Sep-20 Oct-20 Nov-20 Dec-20 Jan-21 Feb-21 Mar-21 Apr-21

- - Number of calls reporting domestic violence $\quad-\quad$-Average, pre-lockdown period $\quad-\quad-$ Average, lockdown period $\quad-\quad-$ Average, post-lockdown period

Fig. 1 Number of calls received on domestic violence, Mitra helpline, Kerala, monthly, October 2019 to April 2021, in numbers. Source: Mitra helpline, Government of Kerala

Table 2 Number of calls received at the three helplines to report domestic violence against women, by type of abuse, Kerala, 23 March to 18 April 2020, in number and \%

\begin{tabular}{lllllll}
\hline Name of helpline & Number of calls & $\begin{array}{l}\text { Number of calls from } \\
\text { direct complainants }\end{array}$ & & \multicolumn{4}{l}{$\begin{array}{l}\text { Number of calls based on type of domestic } \\
\text { abuse }\end{array}$} \\
\cline { 5 - 7 } & & & Physical & Mental & Sexual & Financial \\
\hline Bhoomika & 103 & 58 & 67 & 30 & 4 & 2 \\
Mitra & 77 & 77 & 32 & 44 & 0 & 1 \\
Sakhi & 8 & 7 & 3 & 5 & 0 & 0 \\
Total & $188(100.0)$ & $142(75.5)$ & $102(54.3)$ & $79(42.0)$ & $4(2.1)$ & $3(1.6)$ \\
\hline
\end{tabular}

Source: KILA (2020)

Figures in parenthesis denote percentages to the total number of calls received

fell to 97 calls after the lockdown. Even after the first lockdown was eased in August 2020, there were at least 3 months when the number of calls rose sharply.

One study examined data from three telephonic helplines for women-Mitra, Sakhi and Bhoomika - between 23 March 2020 and 18 April 2020 (KILA, 2020). Over the studied period, the helplines received 188 phone calls (Table 2). Of the 188 calls, 102 calls (54.3 per cent) reported physical abuse and 79 calls (42 per cent) reported mental abuse. Disaggregated data showed that financial constraints were listed by women as the most important reason behind domestic violence, followed 
Table 3 Number of calls received at the three helplines to report domestic violence against women, by perpetrator, Kerala, 23 March to 18 April 2020, in number and \%

\begin{tabular}{llllll}
\hline Name of helpline & \multicolumn{2}{l}{ Relationship with the perpetrator } & & \\
\cline { 2 - 6 } & Husband & Own parents & Parents-in-law & Children & $\begin{array}{l}\text { Other } \\
\text { family } \\
\text { members }\end{array}$ \\
\hline Bhoomika & 62 & 5 & 16 & 9 & 11 \\
Mitra & 65 & 0 & 6 & 0 & 6 \\
Sakhi & 4 & 1 & 1 & 1 & 1 \\
Total & $131(69.7)$ & $6(3.2)$ & $23(12.2)$ & $10(5.3)$ & $18(9.6)$ \\
\hline
\end{tabular}

Source: KILA (2020)

Figures in parenthesis denote percentages to the total number of calls received

by alcoholism and suspicion of infidelity (Table 3). The dominant perpetrator was the husband, followed by parents-in-law.

We must add three riders to this analysis. First, these figures were likely to be underestimates for many reasons, such as fear to approach the helplines, lack of liberty to use a phone, the constant presence of the perpetrator at home, fear of being rendered homeless, fear of the case becoming public and lack of awareness. Secondly, many callers or survivors may suffer from more than one type of domestic violence but may report only one type during the call. A good example would be marital rape, which is not considered and reported as a "crime" in the Indian cultural setting. Thirdly, a finding in most studies was that the absence of alcohol availability during the lockdown reduced drunken domestic violence. Many household surveys in the coastal villages of Kerala consistently reported such a view from women (SRC and TSSS, 2020a, 2020b).

\subsection{Mental health of women}

The lockdown in 2020 appears to have led to a deterioration of mental health among women in Kerala. We analysed data from the Snehitha women's helpdesk of Kudumbashree, which functioned in all the districts (Fig. 2). We analysed the number of calls received and classified as "counselling"; these calls were made by women faced with symptoms of depression, worried about Covid infections and seeking psychosocial assistance due to domestic abuse. The average number of counsellingrelated calls per month to the Snehitha helpline did not increase till June 2020; it rose substantially from July 2020 i.e., three months after the lockdown began. Thus, if an average of 326 calls per month were received before the lockdown, it rose to 335 calls per month during the lockdown and further rose to 358 calls per month in the post-lockdown period. ${ }^{6}$ The number of calls remained high till December 2020 and began to decline only from January 2021.

\footnotetext{
6 The helpline was not operational in April 2020.
} 


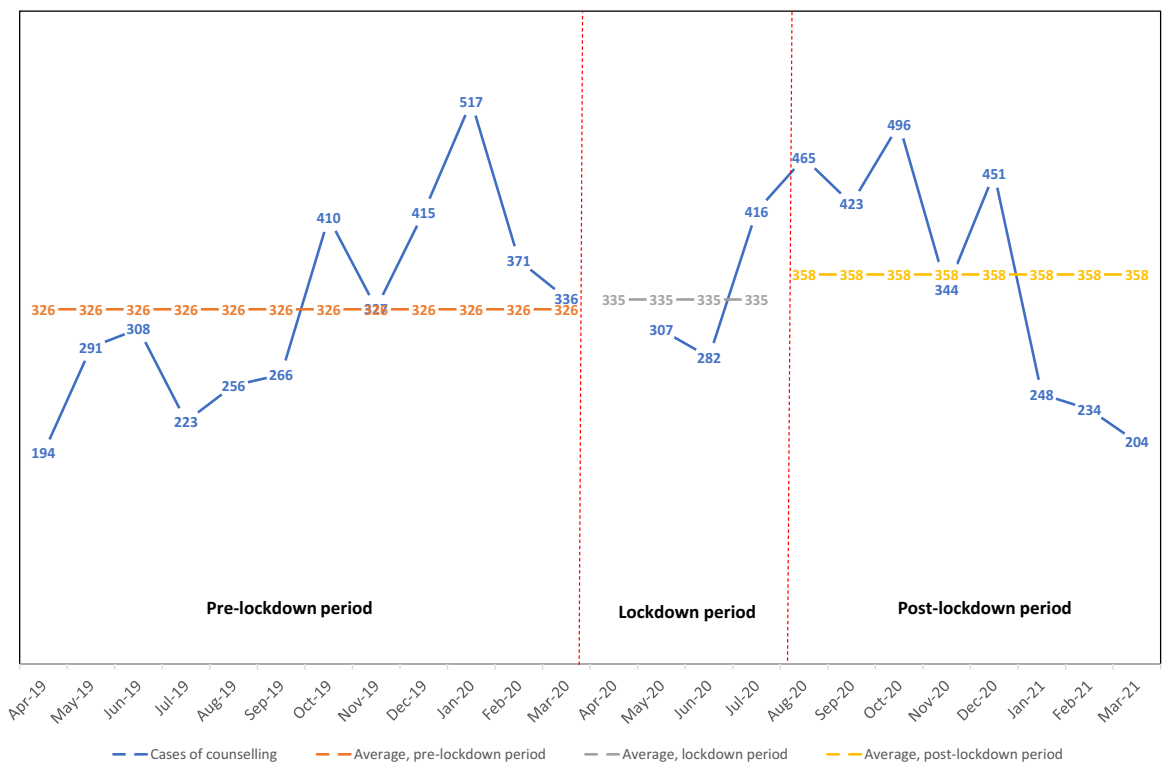

Fig. 2 Number of calls received on counselling, Snehitha helpline, monthly, April 2019 to March 2021, in numbers. Source: Kudumbashree Mission, Government of Kerala

It is probable that the prolonged nature of the lockdown intensified the crisis in mental health; in the initial months, many may have thought of the lockdown as temporary. That the number of calls did not fall even in December 2020 showed the persistence of mental health complaints even after the lockdown was eased in August 2020.

\subsection{Unequal care burdens}

Like any other State in India, Kerala too was home to the unequal burdens at home borne by women. The National Statistical Office's (NSO) Time Use Surveys for 2019 show certain definite features of work distribution at home in Kerala (Table 4). While men participated in larger numbers and spent more time in employment and related activities, women participated in larger numbers and spent more time in unpaid domestic services and unpaid caregiving services for household members. Per day, women spent about three hours more than men in unpaid domestic services and about one hour more than men in unpaid caregiving services.

These patterns of time use are unlikely to have been significantly turned around during the lockdown. Primary surveys in the coastal villages of Thiruvananthapuram in Kerala during the lockdown point to this possibility (SRC \& TSSS, 2020a, 2020b). In Poovar village, 70 per cent of women went out to buy groceries and only 22 per cent of husbands took over the task. Only 34 per cent of the women reported sharing of domestic work with their husbands. In Kulathur village, 84 per cent of 
Table 4 Percentage of people participating and minutes spent per participant in a day, Kerala, by major divisions of major activity classification, 2019, in \% and minutes

\begin{tabular}{|c|c|c|c|c|}
\hline \multirow[t]{2}{*}{ Activity } & \multicolumn{2}{|c|}{$\begin{array}{l}\text { Percentage of people } \\
\text { participating in a day } \\
(\%)\end{array}$} & \multicolumn{2}{|c|}{$\begin{array}{l}\text { Minutes spent in a } \\
\text { day per participant } \\
(\mathrm{min})\end{array}$} \\
\hline & Men & Women & Men & Women \\
\hline Employment and related activities & 49.8 & 16.8 & 497.0 & 395.0 \\
\hline Production of goods for own final use & 7.8 & 10.1 & 106.0 & 80.0 \\
\hline Unpaid domestic services for household members & 31.3 & 80.9 & 107.0 & 303.0 \\
\hline Unpaid caregiving services for household members & 15.2 & 29.0 & 95.0 & 161.0 \\
\hline Unpaid volunteer, trainee and other unpaid work & 3.1 & 3.1 & 178.0 & 145.0 \\
\hline Learning & 17.3 & 18.2 & 438.0 & 437.0 \\
\hline $\begin{array}{l}\text { Socializing and communication, community participation } \\
\text { and religious practice }\end{array}$ & 80.2 & 84.8 & 160.0 & 132.0 \\
\hline Culture, leisure, mass-media and sports practices & 94.1 & 92.2 & 225.0 & 197.0 \\
\hline Self-care and maintenance & 100.0 & 100.0 & 716.0 & 696.0 \\
\hline
\end{tabular}

Source: NSO (2020)

women went out to buy groceries and only eight per cent of husbands shared the burden. Only eight per cent of the women reported sharing of domestic work with husbands. In both villages, men spent most of the time during the lockdown watching television, using mobile phones, playing with children and playing card games with friends in the beach.

Some commentaries have noted that though normative gender roles persisted during the lockdown, "the constant stay at home also forced or created opportunities for men to venture into household chores like cooking and cleaning" (KILA, 2020, p. 9). But it was also true that despite better sharing of work in some spheres, the lockdown led to an increase in the overall workload and anxieties of women and a reaffirmation of their role as the primary caregivers at home.

\section{Public policy and the response to the pandemic}

In this section, we focus on the ways in which the response of the State government involved and engaged with women and their concerns during the lockdown from March 2020 till April 2021. By April 2021, a second wave had begun in Kerala and India; this paper does not deal with the policy responses to the second wave and the second lockdown that followed. ${ }^{7}$

\footnotetext{
7 For a short commentary on the second wave in Kerala, see Ramakumar (2021).
} 


\subsection{Women as frontline health workers}

Kerala's success in containing the pandemic, especially in preventing avoidable deaths, was largely the result of an enlightened state policy and meticulous community-centred mobilisation. Together, they played a critical role in the containment, tracking and monitoring of the health crisis.

The able leadership of Department of Health, led by the State's female minister for health K. K. Shailaja, was pivotal to the State's success. Several global commentaries wrote about Shailaja's role in ensuring early response and instituting a well-oiled machinery of health administration. The Guardian called her a "Coronavirus slayer" and a "rock star health minister" (Spinney, 2020). When asked about the secret behind Kerala's success, her response was: "proper planning" (see also Kabeer, 2020). ${ }^{8}$

At the level of health administration too, women participated in large numbers. Most important among them were the over 8000 nurses and over 5000 junior public health nurses. This workforce-termed by a commentary as the "women of science" - was most effectively used in fighting the pandemic (Mahindru \& Siganporia, 2020).

Standing with the women of science were the "silent, often faceless" essential workers. Kerala's 26,475 Accredited Social Health Activists (ASHA) and about 66,000 anganwadi workers, all of them women, joined hands with the frontline health workers to form a new volunteer force. Joining them were another 325,000 strong youth voluntary brigade members, of whom about 75,000 were young women. Steering the volunteer force were the elected members of Kerala's LSGs spread across 21,900 wards; of these 21,900 wards, 11,826 wards (or 54 per cent) had female elected representatives. Supporting the volunteer force and elected representatives - in strengthening containment procedures and maintaining disciplinewere the State's 30,000 strong police force, of whom 5000 were women.

Most of these essential workers also played a major role in containing the pandemic as part of State-wide campaigns called "Break the Chain" in 2020 and "Crush the Curve" in 2021. Women attached to the Kudumbashree Mission created about 190,000 WhatsApp groups connecting 2.2 million NHG members to educate them about the lockdown guidelines, such as social distancing and sanitisation; this programme was named "Chain Call". Apart from connecting the members of NHGs, the Kudumbashree workers were also trained to take preventive measures against Covid-19 infections and assist in the care of Covid-positive patients, particularly persons with disabilities and the destitute, in their own villages. Once the vaccination drive began in January 2021, Kudumbashree workers were also involved in assisting households in their localities to register for vaccination and ensure that no

\footnotetext{
${ }^{8}$ Naila Kabeer wrote that: "... in a crisis in which women leaders seem to be setting an example, the Health Minister of Kerala, hailed for its remarkably effective response to Covid-19, is also a woman" (Kabeer, 2020). Interestingly, after the State Assembly elections held in April 2021, the ruling Left Democratic Front (LDF) was returned to power for another five years. The new minister for Health and Family Welfare, who took charge in May 2021, was again a woman, Veena George.
} 
household was left out of the vaccination process. Thus, Kudumbashree workers, alongside frontline workers, acted as the eyes, ears, arms and legs of the state on the ground. Their involvement, due to their familiarity with the local population and effective training, substantially expanded and deepened the capacity of the state to intervene during the lockdown. Also, women in Kudumbashree's tailoring microenterprises produced and sold more than 7.2 million cotton masks during the initial months of the lockdown. They also prepared and sold $9323 \mathrm{~L}$ of sanitisers and 96,000 face shields for medical staff through their microenterprises.

At the same time, there was no disproportionate presence of women among either all the infected persons or the number of Covid-related deaths in the State.

First, using a limited dataset of 1.4 million cases from different countries till May 2020, WHO (2020) had noted that 47 per cent of Covid-positive cases were female cases. As part of "The Sex, Gender, and Covid-19 Project", the website https:// globalhealth5050.org reports the global male:female ratio of infections as 50:50. For India, the ratio is reported as 65:35 between July and September 2020, but poor overall testing rates and sex-wise differential access to testing could have distorted the ratio for India (Joe et al., 2020). However, differential access to health services across men and women was less a problem in Kerala than in other States. Sexdisaggregated data was not available for Kerala for any day prior to 28 May 2020. Between 28 May 2020 and 23 February 2021, there were 1.02 million Covid-positive cases in Kerala, out of which 0.45 million (43.8 per cent) were female cases. In short, the share of women infected in Kerala was lower than the global average.

Among all Covid-confirmed cases leading to death, the website https://globalheal th5050.org reports that for every 10 female deaths in the world, there were 13 male deaths (i.e., a male:female ratio of 57:43). But India was an exception to this global trend. For every 10 deaths among confirmed cases in women, there were only 9 deaths among men (i.e., a male:female ratio of 47:53). Two independent analyses for India till September 2020 showed that the Covid-19 CFR was 2.9 per cent for men and 3.3 per cent for women (Dehingia \& Raj, 2020; Joe et al., 2020). At the same time, Kerala was an exception to both the global trend and the Indian trend. For Kerala, we examined nine death audit reports for the months between June 2020 and February 2021. Over this period, there were 4187 Covid-related deaths in the State, out of which only 1130 deaths (or 27 per cent) were of women.

In short, first, in terms of share of Covid-19 infections and share of Covid-related deaths, women in Kerala fared better than women in the world and in India. Secondly, increased involvement of women in pandemic relief in Kerala does not appear to have led to a predominance of women among the cases of infection or deaths.

\subsection{Economic relief}

The State government's economic relief package was one of the first in India. It also covered a wide range of needs of people during the lockdown. In this section, we focus on those aspects of the package with a focus on women and a clear social relief dimension. 


\subsubsection{Cash assistance}

Kerala's social security system for informal workers is one of the most extensive in India. As we discussed in Sect. 2, two sets of measures existed even prior to the pandemic that paid pensions and other forms of social assistance to informal workers.

First, the establishment of Welfare Fund Boards in Kerala was one of the pioneering attempts in India to formalise the workforce in the unorganised sector (Ramakumar, 2006). ${ }^{9}$ There were 16 Welfare Fund Boards under the Government of Kerala that covered about 10 million workers (i.e., more than a third of the State's adult population). Out of these 10 million workers, about 0.47 million workers were super-annuated and were eligible for a monthly pension. We call them Category A. The monthly pension for these beneficiaries in March 2020 was Rs 1400 (US\$ 19). In March 2020, the Government of Kerala announced that it would pay seven months of these pensions in advance to all the beneficiaries. This amounted to a lumpsum cash payment of Rs 9800 (US\$ 133.2) per beneficiary.

Of the 0.47 million pension recipients in all Welfare Fund Boards, 0.26 million or 57.4 per cent were women (see figures for Category $A$ in Table 5). However, within several individual Welfare Fund Boards, a larger proportion of the pension recipients were women. For instance, the share of women members was 97 per cent in the Kerala Tailoring Workers Welfare Fund Board; 95 per cent in the Kerala Cashew Workers Welfare Fund Board; and 90 per cent in the Kerala Bamboo, Eetta, Pandanus Leaf Workers Welfare Fund Board.

Secondly, outside the Welfare Fund Boards, the Government of Kerala covered specific categories of vulnerable sections using a Social Security Pension. About 4.9 million beneficiaries were covered by the Social Security Pensions. We call them Category $B$ in Table 5. Of the 4.9 million beneficiaries, the largest proportion (2.6 million) were the elderly who received old age pensions. Pensions were also distributed to widows (1.4 million), unmarried women of age 50 and above $(86,226)$, the disabled (about 0.4 million), and agricultural labourers (about 0.4 million). These beneficiaries were also provided with seven months of pensions in advance in March 2020.

A significant proportion of the beneficiaries of social security pensions were women, and in some of them all the beneficiaries were women (see figures for Category $B$ in Table 5). About 67 per cent of the beneficiaries of agricultural labourer pension were women; about 46 per cent of the beneficiaries of old age pensions were women; and about 41 per cent of the beneficiaries of disabled persons pension were women.

Once the lockdowns were instituted in March 2020, the Government of Kerala decided to cover an additional third category of 2.8 million beneficiaries with a

\footnotetext{
9 The benefits from Welfare Fund Boards to workers can be divided into three types. First, some Funds provide provident fund benefits to members upon super-annuation, a monthly pension and a gratuity payment. Secondly, some Funds provided social insurance benefits to members, such as a payment for medical treatment or physical disability. Thirdly, some Funds provided different types of welfare assistance to members, such as assistance for children's education, marriage of daughters and construction of houses.
} 
one-time ex-gratia relief payment of Rs 1000 (US\$ 13.6). The beneficiaries of this ex-gratia payment were selected from among the vulnerable workers already registered with the Welfare Fund Boards who were not super-annuated (i.e., not receiving monthly pensions). We call them Category $C$. These workers were paid from the own funds of each Welfare Fund Board. We analysed the share of women among the beneficiaries of this ex-gratia relief payment between April 2020 and April 2021. About 58 per cent of the number of beneficiaries were women, and about 50 per cent of the total amount paid went to women (see figures for Category $C$ in Table 5). ${ }^{10}$

Thus, in all, about 8.2 million beneficiaries were reached with a cash transfer in the first two months of the lockdown. Of them, about 5 million beneficiaries (61 per cent) were women, who almost universally belonged to the working-class population.

\subsubsection{Employment}

5.2.2.1 Rural employment The MGNREGS was the primary instrument available with the government for rural employment generation. This public works scheme aims to provide at least 100 days of wage employment — unskilled manual work-to each rural household in a year. It was not operational in April and May 2020. From June 2020, the State government gave a major boost to the scheme. Officials told us that a few new phenomena were visible from June 2020: one, as there were restrictions on the mobility of older workers, more of the younger members of households came forward to demand work; two, many new households registered in the scheme; three, many migrant workers from other States demanded work in Kerala; and four, the new applicants for work also included the educated, with college degrees.

Further, the nature of works arranged by the government changed with a focus on livelihood generation. For example, more public works were undertaken that generated individual livelihood assets, such as the construction of cattle sheds, poultry sheds and goat sheds in the private lands of beneficiaries. This ensured that workers could work on their own homesteads and avoid crowding at work sites. Also, women played a major role in the functioning of such self-employment vocations.

The policy thrust given to MGNREGS from June 2020 led to a major rise in the number of person-days generated. About 90 per cent of the person-days generated under MGNREGS in Kerala were female person-days. In every month after June 2020, right up to March 2021, the number of female person-days generated exceeded the corresponding figures in 2019-20 (see Fig. 3). Compared to 2019-20, about 20.4 million female person-days were additionally generated in 2020-21 i.e., between April 2020 and March 2021. In all, our data show that 1.6 million female workers received employment under MGNREGS in the 12 months of 2020-21.

5.2.2.2 Urban employment If the MGNREGS catered to the rural areas, the AUEGS catered to the employment guarantee in the urban areas. A similar urban

\footnotetext{
10 The share of beneficiaries and amount do not match here, because some welfare boards paid more than Rs 1000 as ex-gratia relief to tis members.
} 


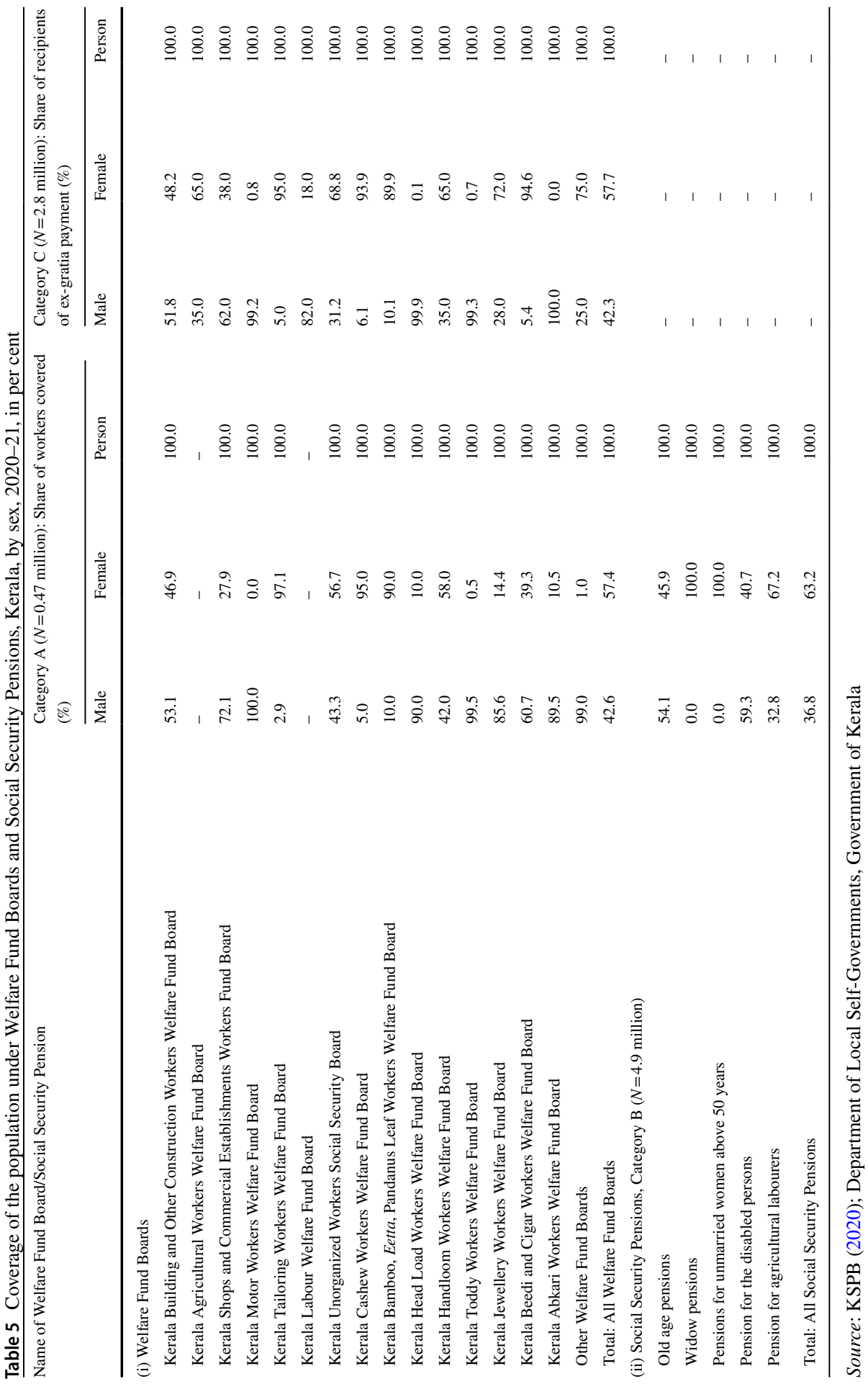




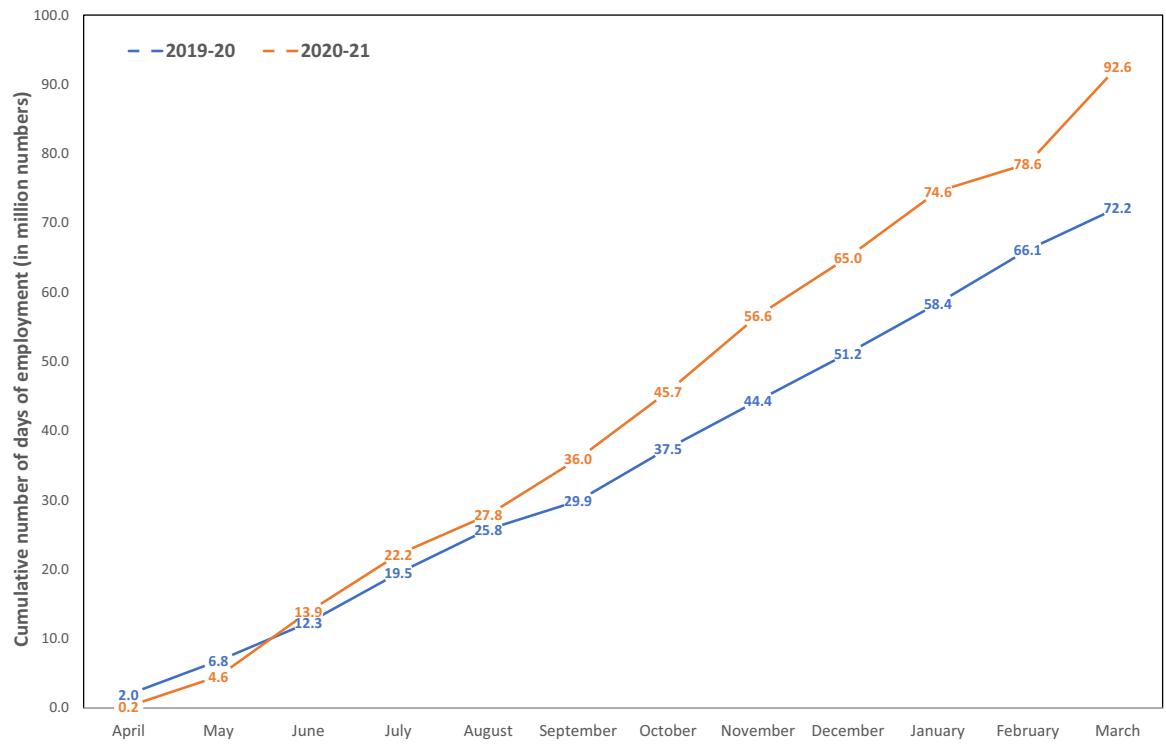

Fig. 3 Cumulative number of female persondays of employment generated under MGNREGS, monthly, Kerala, 2019-20 and 2020-21, in million number of days. Source: Mission Office, MGNREGS, Government of Kerala

employment guarantee scheme did not exist in any other State in India. Like MGNREGS, the AUEGS attempts to guarantee 100 days of wage employmentunskilled manual work - to each urban household in a year. The number of persons provided employment and the number of person-days generated under AUEGS were raised substantially during the lockdown in 2020-21. Right from 2017-18, more than two-thirds of the beneficiaries of AUEGS were women; between 201920 and 2020-21, the share of female beneficiaries rose from 74.7 per cent to 76.8 per cent (Table 6). The number of female person-days of employment also rose by about 429,000 between 2019-20 and 2020-21. The employment created under AUEGS provided much needed relief to unemployed women in urban areas. At the same time, the implementation of AUEGS is still in its initial stages, and much scope exists to expand the scheme's design in terms of depth and reach.

5.2.2.3 100 days programme of employment generation In September 2020, the Government of Kerala announced a special employment programme to address the problem of rising unemployment. It was called the Chief Minister's “Athijeevanam Keraleeyam" programme (or "Kerala Survive"). The aim was to generate self-employment and wage employment for 50,000 persons in 100 days. The Kudumbashree Mission was entrusted with covering 15,000 out of the 50,000 persons. Self-employment, which was to be the focus of the 100-day programme, was to be generated through microenterprises in the non-agricultural sector, agriculture, animal husbandry and in the services sector. All these 15,000 persons were expected to be women. 


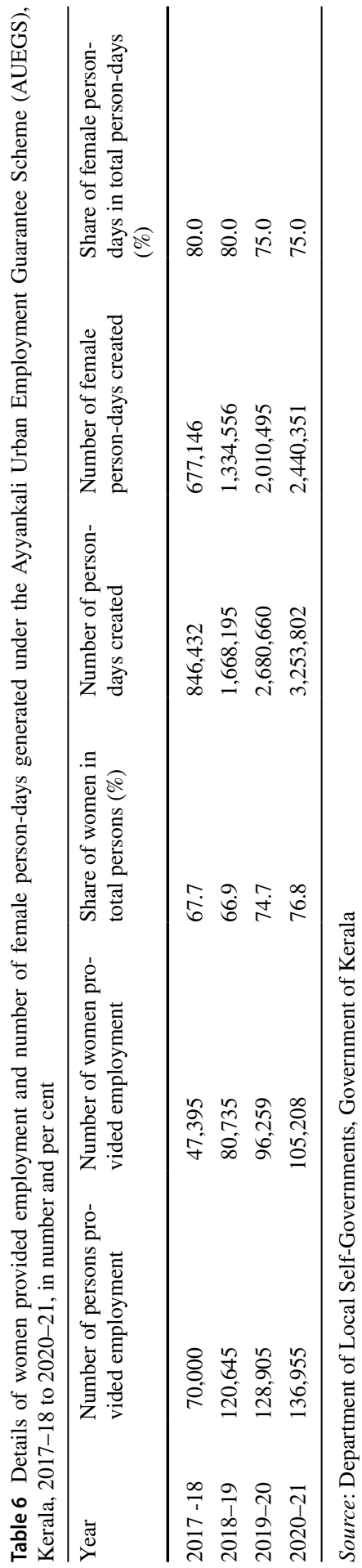


The 100-day programme was a major success. Within the first 100 days, the Kudumbashree Mission covered not 15,000 persons but 36,192 persons. This record of success prompted the government to extend the scheme beyond 100 days. Between September 2020 and March 2021, 43,921 persons were covered by the Kudumbashree Mission alone. Official data show that of these 43,921 persons, 42,447 were women (97 per cent) and 1,474 were men ( 3 per cent). These livelihood-related enterprises created for women were expected to continue functioning even after the pandemic ended.

\subsubsection{Food distribution}

When the lockdown began, the Government of Kerala had announced that no person would go hungry. To realise this aim, the government used two institutional mechanisms it had control over: the public distribution system (PDS) and the local selfgovernments (LSG).

To begin with, Kerala was the first state that began distribution of free food rations to all categories of ration card holders under PDS. The State government provided free rations to 8.7 million ration card holders during the lockdown. Irrespective of the income levels of households, each household was provided a special supply of $15 \mathrm{~kg}$ of food grains (rice or wheat) and $3 \mathrm{~kg}$ of flour (atta). Further, 0.15 million new ration cards were issued to households that did not possess it earlier. The State also initiated steps to distribute free ration to those who did not have ration cards by accepting their Aadhaar numbers. A survey of 504 households in Kerala, between 28 April and 6 May 2020, showed that 92 per cent of ration card holders purchased their allocations from the PDS (CSES, 2020).

Secondly, the State government supplied free food kits, each worth approximately Rs 1000 (US\$ 13.8), to all the 8.7 million ration card holders. Food kits were also provided to about 25,000 non-card holders, welfare organisations, orphanages and religious institutions like convents; here, four people were counted as one family.

Each food kit contained 17 items including $2 \mathrm{~kg}$ wheat flour; $1 \mathrm{~kg}$ each of sugar, salt, green gram, broken wheat, sunflower oil, black gram, bengal gram and sambar dal (pigeon pea); 500 gm of coconut oil; 250 gm of tea powder; 100 gm each of chilli powder, coriander powder, fenugreek, turmeric powder and mustard; two bathing soaps; and one washing soap. Women from the Kudumbashree NHGs actively helped in preparing these kits as well as producing cloth bags for the kits. About 2 million cloth bags were produced by Kudumbashree's tailoring units in April and May 2020. The overwhelming feedback received through the media was that the quality of each product in the kit was good and could be used for a month in one household (Athira, 2021).

Thirdly, the State government started at least one community kitchen in every panchayat. The Kudumbashree Mission and the LSGs were entrusted with leading the programme. In Fig. 4, we have presented the number of community kitchens, the number of meals and the number of free meals provided in the State during the strict lockdown period between March and July 2020. There were 1034 panchayats and urban local bodies in Kerala. At the height of the lockdown in April and May 2020, more than 1100 community kitchens operated in these 1034 
local bodies. In April 2020, an average of more than 200,000 meals per day were provided from these community kitchens. About 89 per cent of these meals were provided free of cost. Even if paid, the price of a meal was just Rs 20 (US\$ 0.27). In May 2020, an average of more than 80,000 meals were provided per day, of which 76 per cent were provided free of cost.

The number of kitchens and the number of meals tapered off as the lockdown was eased in August 2020. But Fig. 4 shows the extraordinary effort made in the State through the mobilisation of political organisations to ensure that no one went hungry during the lockdown. People under institutional and home quarantine also received packed food from community kitchens; volunteers delivered the packets at their quarantine locations. Around 0.3 million inter-State migrant workers residing in Kerala also received the benefit of the community kitchens.

When the lockdown was lifted in August 2020, 379 out of these community kitchens were transformed and institutionalised into the chain of budget hotels of Kudumbashree. These budget hotels continued to provide meals at Rs 20 (US\$ 0.28 ) and was open to public without limits. All these hotels were run by women; they provided a stable means of employment and income to these women.

Fourthly, well before the lockdown began on 24 March 2020, the Government of Kerala had decided to close all pre-schools and schools from the anganwadi level up to Class 7. In this context, the WCD took an innovative step to ensure nutrition to children. It undertook to reach food materials to the homes of all children registered with the anganwadi centres who were aged 3-6 years. These children numbered about 0.37 million across 33,114 anganwadi centres. The scheme

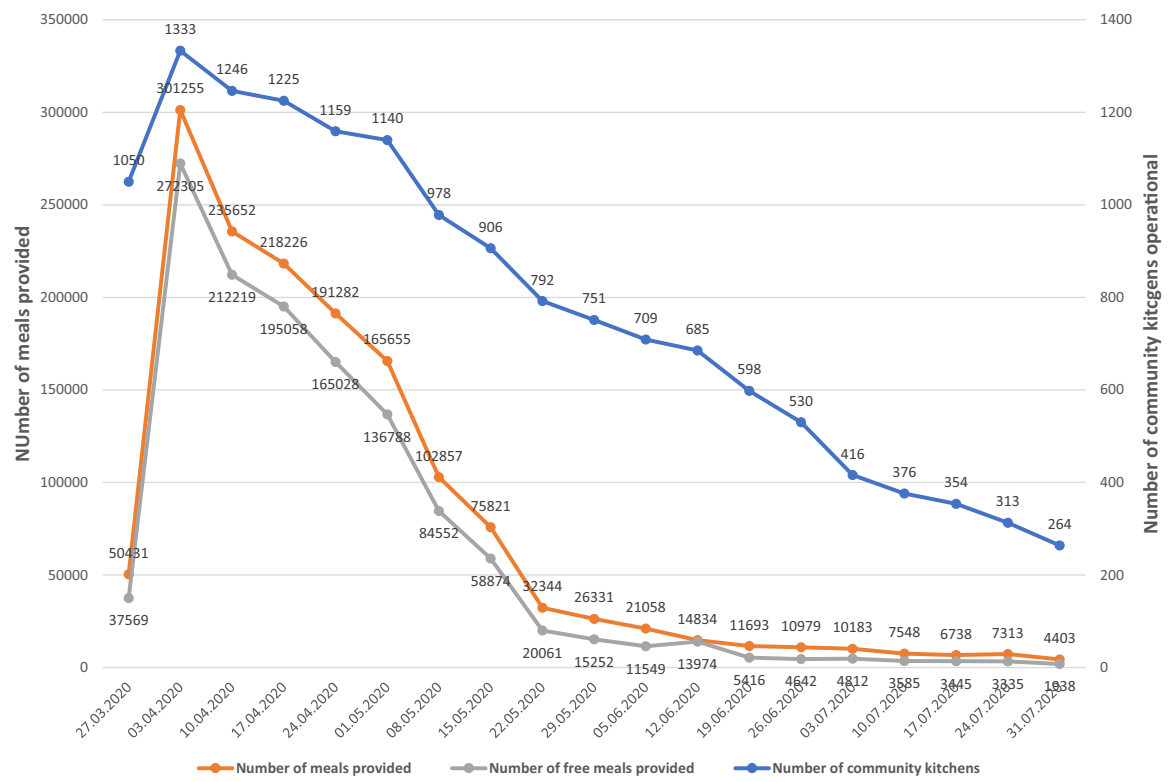

Fig. 4 Total number of community kitchens and total number of meals provided on each day, Kerala, March 2020 to July 2020. Source: Kudumbashree Mission, Government of Kerala 
also covered children aged six months to three years as well as pregnant and lactating mothers.

In sum, the expansion of the PDS, the distribution of food kits, the institution of community kitchens and nutritional assistance to children went a long way in ensuring that no person, irrespective of their sex, social location, age, occupation or domicile went hungry during the lockdown.

\subsubsection{Loans to women}

As part of the economic package, the State government introduced a small-credit facility worth Rs 2000 crore (US\$ 275.4 million) to extend loans to the women in NHGs. Under the scheme, each unit was to receive a loan of size varying from Rs 5000/Rs 10,000/Rs 20,000 (US\$ 69/US\$ 138/US\$ 276). These were zero interest loans whose tenure was 36 months with an initial moratorium period of six months.

By September 2020, the targets were almost met (Table 7). By then, the scheme covered 78 per cent of the NHGs and 66 per cent of the members of NHGs in the State. Of the target of Rs 2000 crore (US\$ 275.4 million), loans amounting to Rs 1817 crore (US\$ 246.9 million, or 91 per cent) had been sanctioned. Data till April 2021 indicated further progress. Of the target of Rs 2000 crore (US\$ 275.4 million), about Rs 1903 crore (US\$ 260.6 million, or 95 per cent) was sanctioned and distributed. In all, the scheme covered 0.21 million NHGs and 2.5 million female beneficiaries.

\subsection{Violence against women}

Helplines like Mitra, Sakhi and Bhoomika were important instruments using which the State government reached out to distressed women during the pandemic. The increase in the number of calls to these helplines was evidence of both rising cases and the visibilisation of the cases through reporting. In addition, the WCD also set up a call centre on WhatsApp that worked $24 * 7$ so that any abuse or violence against women could be intimated. About 51 percent of the calls received at this call centre between 11 and 30 April 2020 were regarding domestic violence.

Our interviews with the helpline managers and police officials showed that a clear process was in place to follow-up on each call. The nature of follow-up depended on the nature of the case. If the case was judged serious, it was referred to the nearest police station. Every police station had a women's cell. In other cases, it was referred to the concerned Women Protection Officer or counselling centre or women's cell or the helpline's own legal counselling cell. In some cases, the helpline returned a call and spoke to the complainant's husband or children. An effort was made to address the matter through these calls. However, if the complainant was keen on exploring legal options, she was referred to the Legal Services Authority from where one person was given charge of the case. All cyber-related cases were reported to the police stations. 
Table 7 Details of the sanction of loans to female members of Kudumbashree NHGs, The Chief Minister's Helping Hand Loan Scheme, Kerala, 1 April 2020 to 24 September 2020, in number, \% and Rs crore and US\$

\begin{tabular}{ll}
\hline Item & $\begin{array}{l}\text { Number/share of Loan amount (in Rs crore and US\$) } \\
\text { NHGs/members }\end{array}$
\end{tabular}

(a) Number of NHGs and members

\begin{tabular}{|c|c|c|}
\hline Total number of NHGs in the State & 283,903 & - \\
\hline Total number of NHGs included in the scheme & 221,366 & - \\
\hline Share of NHGs included in the scheme (\%) & 77.9 & \\
\hline Total number of NHG members in the State & $4,205,426$ & - \\
\hline $\begin{array}{l}\text { Total number of NHG members included in } \\
\text { the scheme }\end{array}$ & $2,761,894$ & - \\
\hline $\begin{array}{l}\text { Share of members included in the scheme } \\
(\%)\end{array}$ & 65.7 & \\
\hline \multicolumn{3}{|l|}{ (b) Details of loan applications } \\
\hline Number of NHGs that have applied for loan & 210,941 & - \\
\hline $\begin{array}{l}\text { Number of members in NHGs that have } \\
\text { applied for loan }\end{array}$ & $2,548,424$ & - \\
\hline Total amount of loan applied for & - & 1975.39 (US\$ 270.9 million) \\
\hline \multicolumn{3}{|l|}{ (c) Details of loans sanctioned } \\
\hline $\begin{array}{l}\text { Number of NHGs whose loans were sanc- } \\
\text { tioned }\end{array}$ & 203,372 & - \\
\hline $\begin{array}{l}\text { Number of members in NHGs whose loans } \\
\text { were sanctioned }\end{array}$ & $2,455,461$ & - \\
\hline Total amount of loan sanctioned & - & 1902.82 (US\$ 260.98 million) \\
\hline \multicolumn{3}{|l|}{ (d) Details of the original scheme } \\
\hline $\begin{array}{l}\text { Total loan amount allocated as per the original } \\
\text { scheme }\end{array}$ & - & 2000.00 (US\$ 274.3 million) \\
\hline
\end{tabular}

Source: Kudumbashree Mission, Government of Kerala

\subsection{Mental health of women}

To begin with, provision of emotional support and psychosocial care to Covid-19 patients and persons staying in quarantine were important aspects of the overall management plan of the government. Due to the experience with the two floods in 2018 and 2019 and the Nipah attack in 2018, Kerala had a well-functioning mental health infrastructure with experience in disaster mental health practices.

In the initial weeks of the pandemic, the DMHP recruited counsellors from the Department of Health Services. But as the pandemic prolonged, they needed more counsellors. About 1050 women counsellors were drawn in from among school counsellors, Integrated Child Protection Scheme (ICPS) counsellors and family counsellors. Kudumbashree recruited 360 new community counsellors; most of the counsellors were women. All helplines were handled by these trained counsellors.

Using these resources, patients admitted to the Covid-19 hospitals and Frontline Treatment Centres (FLTC) and those staying in quarantine were provided with 
psychosocial support over telephone. Special consideration was given to women, adolescents and the elderly. Detailed psychological intervention was undertaken only in those cases with significant levels of distress. Medications were also provided wherever necessary. For each case reported, monitoring was regularly conducted on a weekly basis.

During the lockdown, the government and the Kudumbashree Mission also undertook a special campaign to spread awareness about mental health services including through social media platforms. The by-line of the campaign was "You are not alone; we are with you" and "You are not alone; Kudumbashree is with you".

\section{Conclusions: what made Kerala different?}

Kerala's response to the Covid-19 pandemic in 2020 was positively discussed by scholars and observers across the world. Its success in maintaining CFR at 0.3 even when caseloads were high was seen as an outstanding success. Kerala's response was also noted for the socioeconomic relief measures it provided to people during the lockdown. The government provided not just food provisions and cash support, but it also intervened to reduce violence against women and ensuring psychosocial support to women. Our argument was that Kerala's policy response was commendably "gender-responsive".

Our next argument was that when the pandemic hit in early-2020, Kerala was more ready than any other region in India to confront it; more importantly, this readiness was also gender-responsive. This ability of the State was rooted in its political and socioeconomic history and were products of public action. An early land reform and heavy public investment in education and health had attracted global attention to Kerala's development experience by the 1970s itself. From the 1990s, Kerala decentralised its health system and expanded community participation in health care. It also designed and implemented targeted policies to empower women and encourage their political participation.

We, thus, argued that Kerala confronted the pandemic standing on the shoulders of a rich legacy of public action. On the health front, women were in the forefront of Kerala's pandemic response strategy. On the socioeconomic front, women in Kerala were as affected by the pandemic as any other region of the world. But the State government instituted a substantial economic relief package. The package included a cash assistance to about eight million people, free food for all, supply of free food kits for all, community kitchens, expansion of rural and urban employment and loans to women in distress. We showed the conscious attempt of the State's government to integrate women as major beneficiaries in all these interventions. Effective helpline support measures were introduced to address violence against women and providing them psychosocial support. Without its history of people-centric and gender-sensitive public action, Kerala would not have been able to react to the pandemic with the swiftness and effectiveness as it did.

The lessons from Kerala appear simple in development policy. But its implications are powerful for the life and work of women everywhere. Development policy everywhere must centrally accommodate issues and concerns related to gender. 
While the world tries to "build back fairer", Kerala's case is a rich guide both as a demonstration of the possibilities of gender-responsive policy and as a reminder of the essential pre-conditions to achieve it.

Author contributions We declare that all the contributions made to this paper titled The legacy of public action and gender-responsive pandemic responses in Kerala State, India are our original contributions, and all credit has been provided for all the secondary material collected.

Funding We declare that we have not received any funding from either the Government of Kerala/India or any other independent organization in writing this paper titled The legacy of public action and genderresponsive pandemic responses in Kerala State, India.

\section{Declarations}

Conflict of interest We declare that apart from being independent economists, we were also members of the Kerala State Planning Board (KSPB) between September 2016 and April 2021. The KSPB is an advisory body of the Government of Kerala in designing its development policies. This paper titled The legacy of public action and gender-responsive pandemic responses in Kerala State, India is an analysis of the pandemic response policies of the Government of Kerala also.

Ethics statement We declare that in writing the paper titled The legacy of public action and genderresponsive pandemic responses in Kerala State, India we have ensured that all academic and research principles related to ethics were adhered to.

\section{References}

Agarwal, B. (2020). A tale of two experiments: institutional innovations in women's group farming in India. Canadian Journal of Development Studies, 41(2), 169-192. https://doi.org/10.1080/02255 189.2020.1779673

Agarwal, B. (2021a). Livelihoods in Covid times: gendered perils and new pathways in India. World Development, 139, 105312. https://doi.org/10.1016/j.worlddev.2020.105312

Agarwal, B. (2021b). Imperatives of recognising the complexities: Gendered impacts and responses to Covid-19 in India. Economia Politica (special Issue on Pandemics, Women and the Global South, Forthcoming). https://doi.org/10.1007/s40888-021-00242-8

Alon, T., Doepke, M., Olmstead-Rumsey, J., \& Tertilt, M. (2020). The impact of Covid-19 on gender equality. NBER Working Paper 26947. https://doi.org/10.3386/w26947.

Athira, M. (2021, January 21). Why Malayali households went back to ration shops during the pandemic. The Hindu, Retrieved on February 28, 2021, from https://bit.ly/2O86Iqi.

CDS. (1975). Poverty, unemployment and development policy: a case study of selected issues with reference to Kerala. Centre for Development Studies, Orient Longman.

Chathukulam, J., \& Tharamangalam, J. (2021). The Kerala model in the time of Covid-19: Rethinking state, society and democracy. World Development, 137(105207), 1-13. https://doi.org/10.1016/j. worlddev.2020.105207

Croda, E., \& Grossbard, S. (2021). Women pay the price of Covid-19 more than men. Review of Economics of the Household, 19, 1-9. https://doi.org/10.1007/s11150-021-09549-8

CSES (2020). Consumption behaviour of Malayalis during lockdown. Kochi: Centre for Socioeconomic and Environmental Studies (CSES). Retrieved on February 28, 2021, from https://bit.ly/3bDF4cQ.

Das, S. (2019). Promises and priorities: An analysis of union budget 2019-20. New Delhi: Centre for Budget and Governance Accountability (CBGA). Retrieved on February 28, 2021, from https://bit. ly/3r5iNLF.

Dehingia, N., \& Raj, A. (2020). Sex differences in COVID-19 case fatality: do we know enough? The Lancet, 9, e14-e15. https://doi.org/10.1016/S2214-109X(20)30464-2 
Eapen, M. (2021). Integrating gender responsive budgeting into planning: Kerala's experience. Gender Mainstreaming in India: Perspectives and Concerns. Fiscal Policy Institute.

Elamon, J., Franke, R. W., \& Ekbal, B. (2004). Decentralization of health services: the Kerala people's campaign. International Journal of Health Services, 34(4), 681-708. https://doi.org/10.2190/ 4L9M-8K7N-G6AC-WEHN

Franke, R. W. (1993). Life is a little better: redistribution as a development strategy in Nadur village, Kerala. Boulder and Oxford: Westview Press.

George, K. K. (1990). Kerala's fiscal crisis: A diagnosis. Economic and Political Weekly., 25(37), 2097-2105.

GoK (2021). Reduction in all-cause mortality in Kerala during Covid-19 pandemic. Technical paper, Department of Health \& Family Welfare, Thiruvananthapuram: Government of Kerala. Retrieved on February 28, 2021, from https://bit.ly/37RluZy.

Heller, P. (2020, April 18). A virus, social democracy, and dividends for Kerala. The Hindu. Retrieved on February 28, 2021, from https://bit.ly/37Wv8ue.

Herring, R. J. (1980). Abolition of landlordism in Kerala: a redistribution of privilege. Economic and Political Weekly, 15(26), A59-A69.

Jeffrey, R. (1987). Governments and culture: How women made Kerala literate. Pacific Affairs, 60(3), 447-472.

Jeffrey, R. (1993). Politics, women and well-being: how Kerala became 'a model.' Oxford University Press.

Jishnudas, K. S. (2020). Public action and educational development in Malabar with special reference to the Taliparamba south sub-district. MA dissertation. Tata Institute of Social Sciences.

Joe, W., Kumar, A., Rajpal, S., Mishra, U. S., \& Subramanian, S. V. (2020). Equal risk, unequal burden? Gender differentials in Covid-19 mortality in India. Journal of Global Health Science., 2(1), 1-15. https://doi.org/10.35500/jghs.2020.2.e17

Kabeer, N. (2020, May 18). Labour market inequalities are exacerbated by Covid-19. LSE Blogs. Retrieved February 28, 2021, from https://bit.ly/2O4Szu7.

KILA (2020). Domestic violence and issues experienced by the women and girls of Kerala during the Corona lockdown period: A study report. Thrissur: Kerala Institute of Local Administration (KILA).

Kodoth, P., \& Eapen, M. (2005). Looking beyond gender parity: gender inequities of some dimensions of well-being in Kerala. Economic and Political Weekly, 40(30), 3278-3286.

Krishnan, T. N. (1991). "Kerala's health transition: facts and factors". Monograph. Thiruvananthapuram: harvard centre for population and development studies and centre for development studies.

KSPB (2020). Quick assessment of the impact of the Covid-19 pandemic and lockdown on Kerala's economy. Thiruvananthapuram: Kerala State Planning Board.

KSPB (2021a). Economic Review 2020, Thiruvananthapuram: Kerala State Planning Board.

KSPB (2021b), Kerala development report: Initiatives, achievements and challenges. Thiruvananthapuram: Kerala State Planning Board.

Linde, A. \& Gonzalez, A. (2020, May 8). The pandemic's gender imperative. The Project Syndicate. Retrieved February 28, 2021, from https://bit.ly/37SAJlb.

Mahindru, M., \& Siganporia, S. (2020, October 18). The Coronavirus slayers: Meet the female leaders on India's Covid-19 frontline. Vogue. Retrieved on February 28, 2021, from https://bit.ly/37WbvCx.

Maya, C. (2012, April 6). PHCs to provide mental health care. The Hindu, Retrieved on February 28, 2021, from https://bit.ly/2O7VHWh.

Mukherjee-Reed, A. (2015). Taking solidarity seriously: a movement for gender justice in India. In P. Utting (Ed.), Social and solidarity economy: beyond the fringe? Zed Books.

Namboodiripad, E. M. S. (1948). Agrarian question in Kerala. New Delhi: People's Publishing House.

NSO (2020). Time use in India-2019. New Delhi: National Statistical Office, Government of India.

Palepu, N. (2020, July 23). Improving India's mental healthcare: A case study of Kerala. New Delhi: Observer Research Foundation. Retrieved on February 28, 2021, from https://bit.ly/2ZTAdPo.

Parayil, G. (Ed.). (2000). Kerala's Development Achievements: Issues of Sustainability and Replicability. London: Zed Press.

PTI (2020, June 26). Kerala gets Amartya Sen's praise for the way it handled Covid-19. NDTV. Retrieved on February 28, 2021, from https://bit.ly/2O4VvXF.

Ramachandran, M. T., \& Das, A. (2020). Collective farming and women's livelihoods: a case study of Kudumbashree group cultivation. Canadian Journal of Development Studies, 41(4), 525-543. https://doi.org/10.1080/02255189.2020.1799764 
Ramachandran, V. K. (1996). On Kerala's development achievements. In J. Dreze \& A. Sen (Eds.), Indian development: selected regional perspectives (pp. 205-356). Oxford University Press.

Ramakumar, R. (2021), Kerala's exemplary record in Covid-19 management. Peoples Democracy. 8 August, https://bit.ly/39b2DZP.

Ramakumar, R. (2006). Public action, agrarian change and the standard of living of agricultural workers: a study of a village in Kerala. Journal of Agrarian Change., 6(3), 306-345. https://doi.org/10. 1111/j.1471-0366.2006.00124.x

Ramankutty, V. (2000). Historical analysis of the development of health care facilities in Kerala State, India. Health Policy and Planning, 15(1), 103-109. https://doi.org/10.1093/heapol/15.1.103

Rawal, V., \& Bansal, V. (2021). "The Land Question in Contemporary Rural India”, in Ramakumar, R. (ed.) A Hard Time: Indian Agriculture after Liberalisation, New Delhi: Tulika Books, forthcoming.

Sen, A. (1999). Development as freedom. Oxford University Press.

Spinney, L. (2020, May 14). The coronavirus slayer! How Kerala's rock star health minister helped save it from Covid-19. The Guardian. Retrieved on February 28, 2021, from https://bit.ly/3r5DrLQ.

SRC \& TSSS. (2020a). Gender and impact of Covid-19 in the project area of Pulluvila Forane. Sakhi Resource Centre and Trivandrum Social Service Society.

SRC \& TSSS. (2020b). Gender and impact of Covid-19 in the project areas of Anjengo and Puthukurichy Forane. Sakhi Resource Centre and Trivandrum Social Service Society.

Swaminathan, M., \& Johnson, D. (2020, April 22). Kerala's approach to containing corona. Business Standard. Retrieved on February 28, 2021, from https://bit.ly/3q7ooA0.

Tharakan, M. (1984). Socioeconomic factors in educational development: case of nineteenth century Travancore. Economic and Political Weekly., 19(45), 1913-1928.

Thomas Isaac, T. M., \& Franke, R. W. (2002). Local democracy and development: the Kerala people's campaign for decentralized planning. Rowman \& Littlefield.

Thomas Isaac, T. M., \& Sadanandan, R. (2020). Covid-19, public health system and local governance in Kerala. Economic and Political Weekly., 55(21), 35-40.

UN Women (2020). From insights to action: Gender equality in the wake of Covid-19. UN Women. e-ISBN: 978-92-1-005339-6.

United Nations (2020, April 6). UN chief calls for domestic violence 'ceasefire' amid 'horrifying global surge'. Retrieved on February 28, 2020, from https://bit.ly/2ZXmAio.

Wenham, C., Smith, J., Davies, S. E., Feng, H., Grépin, K. A., Harman, S., Herten-Crabb, A., \& Morga, R. (2020). Women are most affected by pandemics-Lessons from past outbreaks. Nature, 583, 194-198. https://doi.org/10.1038/d41586-020-02006-Z

WHO (2020a, July 2). Responding to Covid-19: Learnings from Kerala. Retrieved on February 28, 2021, from https://bit.ly/3q0GDH2.

WHO (2020b, May 14). Gender and Covid-19: Advocacy brief. Retrieved on February 28, 2021, from https://bit.ly/3r2X7Qr.

Williams, G., Thampi, B. V., Narayana, D., Nandigama, S., \& Bhattacharyya, D. (2011). Performing participatory citizenship_-Politics and power in Kerala's Kudumbashree programme. The Journal of Development Studies, 47(8), 1261-1280. https://doi.org/10.1080/00220388.2010.527949

Publisher's Note Springer Nature remains neutral with regard to jurisdictional claims in published maps and institutional affiliations. 